\title{
25. TITANOMAGNETITE OXIDATION STATE AND AGE OF BASALTS FROM ODP HOLE 648B ${ }^{1}$
}

\author{
Nikolai Petersen ${ }^{2}$ and Hojatollah Vali ${ }^{3}$
}

\begin{abstract}
The titanomagnetite oxidation state of "zero age" ocean floor basalts was investigated. For this purpose the oxidation parameter, z, of Hole 648B basalts was determined by SEM observation of "shrinkage cracks" in individual titanomagnetite grains and by Curie temperature measurements. A mean z-value of 0.1 has been deduced for the Hole 648B basalts.

Assuming a linear relationship between titanomagnetite low-temperature oxidation state and age of the oceanic basalt, an age of $0.7 \mathrm{~m} . \mathrm{y}$. is deduced for Hole $648 \mathrm{~B}$.
\end{abstract}

\section{INTRODUCTION}

The deep ocean environment causes a special form of alteration of the basaltic basement which proceeds slowly but gradually at ambient temperatures. This process of submarine "weathering" affects also the magnetic minerals contained in ocean floor basalts, which in turn has consequences for the magnetization of the oceanic crust and hence also for the shape and amplitude of the marine magnetic anomalies.

Various characteristics of the amplitude variation of the marine magnetic anomalies have been ascribed to the process of submarine magnetic mineral alteration, in particular the prominence of the central anomaly and the gradual decrease in amplitude with increasing age on both sides away from an active spreading center (e.g., Irving, 1970; Prévot, 1973; Prévot and Grommé, 1975; Bleil and Petersen, 1983).

It is of interest in this context to study the magnetomineralogy of ocean floor basalts right after emplacement at the ridge crest, i.e., by analyzing "zero-age crust." Up to now only dredge-samples of zero-age crust have been studied in this regard. But these samples may not be representative of the more deep-seated sources of the marine magnetic anomalies. Although ODP Hole 648B failed to achieve a deep penetration of zero-age crust, it is nevertheless the best collection of a vertical profile into very young oceanic basalt that can be used for such a study.

We would like to address the question of whether or not the magnetic minerals in "zero age crust" are indeed completely unaltered, or if some degree of deuteric alteration built up during the primary cooling of the rock is already present. Another alternative is the assumption that the crust investigated is not really of zero age. In a further step an age estimate of the drill site is attempted from the degree of titanomagnetite low-temperature oxidation.

\section{SUB-OCEANIC TITANOMAGNETITE ALTERATION}

Titanomagnetite $\left(\mathrm{Fe}_{3-\mathrm{x}} \mathrm{Ti}_{\mathrm{x}} \mathrm{O}_{4}, \mathrm{O} \leq \mathrm{x} \leq 1\right)$ is the dominant magnetic mineral in ocean floor basalt. Under suboceanic conditions it changes gradually its mineralogic state due to

\footnotetext{
${ }^{1}$ Detrick, R., Honnorez, J., Bryan, W. B., Juteau, T., et al., 1990. Proc. ODP, Init. Repts., 106/109: College Station, TX (Ocean Drilling Program).

2 Institut für Geophysik, Ludwig Maximilians Universität München, Theresienstr. 41, D-8000 Munich 2, Federal Republic of Germany.

${ }^{3}$ Lehrstuhl für Mineralogie, TU-München, Lichtenbergstr. 4. D-8046 Garching, Federal Republic of Germany.
}

low-temperature oxidation. The result of this form of oxidation is the production of increasing cation deficiency in the titanomagnetite crystals caused by migration of Fe-ions out of the spinel lattice (Prévot et al., 1968; Marshall and Cox, 1972; Petersen et al., 1979; Housden, 1986). The resulting monophasic nonstoichiometric spinel products are referred to as titanomaghemites.

Under the reflected light microscope, titanomagnetite low-temperature oxidation is recognized by a slight change in color, a transition from the original reddish brown to a more grayish appearance, eventually becoming bright grayish. Another characteristic of low-temperature oxidized titanomagnetite is the formation of irregular, curved cracks in the crystals. These cracks were first described by Katsura and Kushiro (1961) in mildly metamorphosed continental basalts. Larson and Strangway (1969) were the first to interpret them as due to volume change associated with the process of maghemitization (shrinking of the spinel lattice). Following Johnson and Hall (1978) we will call them "shrinkage cracks.",

The observation of shrinkage cracks in titanomagnetite grains is a very sensitive method to determine the onset of low-temperature oxidation (Petersen and Vali, 1987) and will be used in this study.

The titanomagnetite oxidation state can be described quantitatively by the oxidation parameter $\mathrm{z}$ as defined by O'Reilly and Banerjee (1967):

$$
\mathrm{z}=\Delta \mathrm{Fe}^{2+} / \mathrm{Fe}^{2+} \text { initial }(0 \leq \mathrm{z} \leq 1)
$$

where $\Delta \mathrm{Fe}^{2+}$ is the amount of initial $\mathrm{Fe}^{2+}$ converted to $\mathrm{Fe}^{3+}$.

As the magnetic properties of titanomagnetite change in a systematic way with increasing $\mathrm{z}$, the oxidation parameter $\mathrm{z}$ can in turn be determined by the measurement of certain magnetic parameters. The measurement of the Curie temperature $T_{c}$ is a good example, although certain assumptions have to be made for a quantitative estimate of $\mathrm{z}$ as will be discussed further below.

\section{INSTRUMENTS AND METHODS}

\section{Thermomagnetic analysis}

Curie temperatures $\left(T_{c}\right)$ and specific saturation magnetization $\left(I_{S}\right)$ were determined by measuring the temperature dependence of the strong field induced magnetization (thermomagnetic curve) with a Forrer-type automatic recording translation balance. The applied field was $5000 \mathrm{Oe}\left(4 \times 10^{5} \mathrm{~A} / \mathrm{m}\right)$ The measurements were carried out in air. 
The heating rate was $50^{\circ} \mathrm{C} / \mathrm{min}$, which proved to be sufficiently high to prevent a noticeable increase of $\mathrm{T}_{\mathrm{c}}$ due to titanomagnetite oxidation. From the thermomagnetic curves, the Curie temperatures were determined by the graphical method of Grommé et al. (1969).

\section{Reflected light microscopy}

Polished sections were studied under reflected light with a Leitz Orthoplan-Pol microscope. Magnetic colloid was used to aid the identification of magnetic minerals.

\section{Scanning electron microscopy (SEM)}

For the detection of shrinkage cracks isolated titanomagnetite grains, separated from the basalt matrix, were studied by SEM observation. The advantage of this method compared to light microscopy is to obtain a spatial view of the grains.

The samples were crushed in an agate mortar to an average grain size of about $50 \mu \mathrm{m}$. Then the titanomagnetite grains were magnetically extracted from a water slurry. To clean the titanomagnetite grains from adhering relics of the silicate matrix, the material was treated in $5 \mathrm{~N} \mathrm{NaOH}$ at $75^{\circ} \mathrm{C}$ for up to $40 \mathrm{hr}$. After washing, the material was treated with $10 \%$ hydrofluoric acid for different lengths of time. For SEM observation a thin veneer of the powder was placed on a specimen mount and coated with gold.

\section{DETERMINATION OF THE TITANOMAGNETITE OXIDATION PARAMETER $Z$}

The titanomagnetite oxidation parameter $\mathrm{z}$ has been determined qualitatively by SEM-observation of "shrinkage cracks" in individual titanomagnetite grains: the absence of any shrinkage cracks is good evidence for a very low oxidation state $z \leq 0.2$ (Petersen and Vali, 1987). The deeper any shrinkage cracks penetrate the titanomagnetite grains, the higher the titanomagnetite oxidation state. Comparative studies on stoichiometric titanomagnetite show that the cracks are not generated by the treatment with acid. Equivalent experiments on stoichiometric synthetic titanomagnetite show only the formation of etch pits and no indication of any crack development.
The parameter $\mathrm{z}$ has also been deduced from Curie temperature measurements which gives a more quantitative estimate. This method of z-determination assumes that the original titanomagnetite composition prior to any alteration is more or less the same in all MORB basalts (Johnson and Melson, 1978; Petersen et al., 1979; Housden, 1986). For the conversion of $\mathrm{T}_{c}$ to $\mathrm{z}$-values the curve of Petersen et al. (1979) was used, where a primary titanomagnetite composition of

$$
\mathrm{Fe}_{2.27} \mathrm{Ti}_{0.58} \mathrm{Al}_{0.07} \mathrm{Mg}_{0.06} \mathrm{Mn}_{0.02} \mathrm{O}_{4}
$$

with Curie temperature $\mathrm{T}_{\mathrm{c}}=125^{\circ} \mathrm{C}$ for $\mathrm{z}=0$ was assumed.

\section{MAGNETOMINERALOGY}

The magnetomineralogy of the samples investigated is very similar to that known from other young and little altered MORB basalts (Fig. 1). The dominant magnetic mineral is titanomagnetite, $\mathrm{Fe}_{3-\mathrm{x}} \mathrm{Ti}_{\mathrm{x}} \mathrm{O}_{4}(0 \leq \mathrm{x} \leq 1)$. The range of compositions of the primary titanomagnetites in tholeiitic oceanic basalts, prior to any alteration, is very limited, with $\mathrm{x}$-values between 0.56 and 0.60 (Johnson and Melson, 1978; Petersen et al., 1979; Housden, 1986).

The titanomagnetite content of the samples, determined microscopically from the polished sections, varies between $0.5 \%$ and $2 \%$. A volume content of $1 \%$ is typical for the more fine grained samples, being slightly higher in the more coarse grained ones. This is also expressed in a higher intensity of saturation magnetization (Table 1).

The titanomagnetite grains are anhedral to skeletal (Fig. 2A and $-\mathrm{B}$ ) with grain sizes varying from almost invisible under the light microscope (e.g., 1R-2, 62-64 cm) to approximately $100 \mu \mathrm{m}$ (e.g., 18R-1, 25-27).

Primary ilmenite, typically forming separate laths, could be identified in all the samples (Fig. 2A and -B). The ilmenite does not contribute to the natural magnetization of the rocks as its Curie temperature is close to $-150^{\circ} \mathrm{C}$.

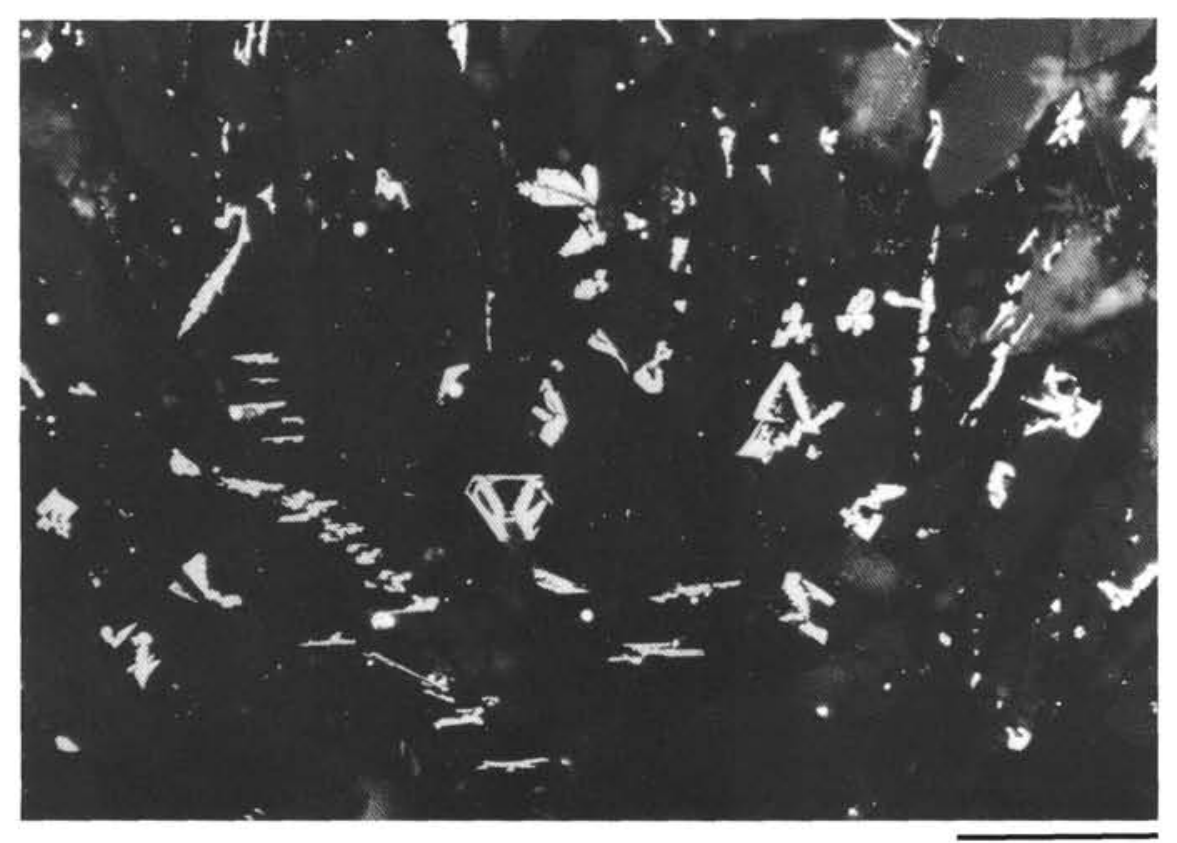

Figure 1. Polished section of Sample 648B-6R-1, 53-54 cm. Different ore components are visible: titanomagnetite (light grey, skeletal shape), ilmenite (light grey, lath-shaped), ironsulfide (white, globules). The bar represents $100 \mu \mathrm{m}$. 
Table 1. Rock magnetic properties and titanomagnetite oxidation state of Hole 648B basalts.

\begin{tabular}{|c|c|c|c|c|c|}
\hline Sample & $\begin{array}{l}\text { Specific saturation } \\
\text { magnetization } \\
\left.\text { (Gauss } \mathrm{cm}^{3} / \mathrm{g}\right)\end{array}$ & $\begin{array}{c}\mathrm{NRM}^{\mathrm{a}}\left(10^{-3}\right. \\
\text { Gauss })\end{array}$ & $\begin{array}{c}\mathrm{MDF}^{\mathrm{a}} \\
(\mathrm{Oe})\end{array}$ & $\begin{array}{c}\text { Curie temp. } \\
\left({ }^{\circ} \mathrm{C}\right)\end{array}$ & $\begin{array}{l}\text { Oxidation } \\
\text { parameter } \\
\text { (z) }\end{array}$ \\
\hline $1 \mathrm{R}-1,87-89 \mathrm{~cm}$ & 0.45 & - & - & 142 & 0.13 \\
\hline $1 \mathrm{R}-2,6-8 \mathrm{~cm}$ & 0.27 & 7.86 & 231 & 180 & 0.35 \\
\hline $1 \mathrm{R}-2,62-64 \mathrm{~cm}$ & 0.51 & 13.24 & 72 & 111 & 0 \\
\hline $\mathrm{IR}-3,83-85 \mathrm{~cm}$ & 0.51 & 7.44 & 60 & 127 & 0.01 \\
\hline $3 \mathrm{R}-1,52-53 \mathrm{~cm}$ & 0.42 & 13.71 & 73 & 116 & 0 \\
\hline $4 \mathrm{R}-1,32-34 \mathrm{~cm}$ & 0.35 & 11.54 & 72 & 142 & 0.13 \\
\hline $5 \mathrm{R}-1,17-19 \mathrm{~cm}$ & 0.45 & 7.52 & 116 & 152 & 0.20 \\
\hline $6 \mathrm{R}-1,53-54 \mathrm{~cm}$ & 0.59 & - & - & 167 & 0.29 \\
\hline $6 \mathrm{R}-1,75-77 \mathrm{~cm}$ & 0.78 & 4.04 & 41 & 159 & 0.24 \\
\hline $6 \mathrm{R}-1,134-135 \mathrm{~cm}$ & 0.70 & 19.80 & 47 & 162 & 0.26 \\
\hline $8 \mathrm{R}-1,55-57 \mathrm{~cm}$ & 0.62 & 9.46 & 73 & 149 & 0.19 \\
\hline $9 \mathrm{R}-1,51-53 \mathrm{~cm}$ & 0.54 & 11.71 & 23 & 122 & 0 \\
\hline $15 \mathrm{R}-1,1-3 \mathrm{~cm}$ & 0.52 & 3.52 & 149 & 134 & 0.08 \\
\hline $15 \mathrm{R}-1,82-84 \mathrm{~cm}$ & 0.54 & 10.20 & 57 & 136 & 0.09 \\
\hline $16 \mathrm{R}-1,24-26 \mathrm{~cm}$ & 0.63 & 3.80 & 17 & 139 & 0.11 \\
\hline $16 \mathrm{R}-1,84-86 \mathrm{~cm}$ & 0.61 & 4.59 & 95 & 212 & 0.48 \\
\hline $18 \mathrm{R}-1,10-12 \mathrm{~cm}$ & 0.74 & 9.34 & 56 & 189 & 0.39 \\
\hline $18 \mathrm{R}-1,25-27 \mathrm{~cm}$ & 0.76 & 8.09 & 65 & 184 & 0.37 \\
\hline $20 \mathrm{R}-1,10-12 \mathrm{~cm}$ & 0.51 & 13.49 & 74 & 124 & 0 \\
\hline Mean value & 0.55 & 9.37 & 78 & 150 & 0.15 \\
\hline $\begin{array}{l}\text { Standard } \\
\text { deviation }\end{array}$ & 0.14 & 4.32 & 50 & 27 & 0.14 \\
\hline
\end{tabular}

a 1 Gauss $\mathrm{cm}^{3} / \mathrm{g}=1 \mathrm{~A} \mathrm{~m}^{2} / \mathrm{kg} ; 1$ Gauss $=10^{3} \mathrm{~A} / \mathrm{m} ; 1 \mathrm{Oe}=80 \mathrm{~A} / \mathrm{m}$.

Iron-sulfides are also commonly present, often as perfect spherules (Fig. 3). Their volume content is less than $0.1 \%$. Although most of the sulfides are probably pyrrhotite which is ferromagnetic at ambient temperatures, their contribution to the bulk magnetization of the rock is negligible.

\section{TITANOMAGNETITE OXIDATION STATE}

The conversion of Curie temperature $T_{c}$ in oxidation parameter $\mathrm{z}$-values is given in Table 1 . We find a considerable $\mathrm{z}$-range, from $\mathrm{z}=0$ to $\mathrm{z}=0.5$, with a mean value of $\mathrm{z}=0.15$. Table 2 gives a juxtaposition of different magnetic parameters of Hole 648B samples and samples from the FAMOUS area (Prévot et al., 1979). The mean value of the titanomagnetite oxidation parameter $\mathrm{z}$ is the same for both localities.

The corresponding SEM observations agree well with the magnetically determined z-values. Figure 4 shows as an example Sample $18 \mathrm{R}-1,25-27 \mathrm{~cm}$, with a magnetically determined $\mathrm{z}=0.37$. Here, well developed shrinkage cracks are visible, in contrast to Sample $3 \mathrm{R}-1,51-53 \mathrm{~cm}$ ) with $\mathrm{z}=0$ which shows no sign of any shrinking (Fig. 5). For comparison a synthetic equivalent with $\mathrm{z}=0$ is treated the same way and shows the same behavior: no shrinkage cracks are visible, only etch pits.

It is interesting to note that the oxidized samples showing shrinkage cracks exhibit hardly any etch pits, whereas the nonoxidized titanomagnetites are full of etch pits indicating a high density of lattice defects. No ilmenite exsolution lamellae as indication of titanomagnetite high-temperature deuteric oxidation could be detected.

\section{AGE-ESTIMATE OF 648B HOLE BASALTS}

In submarine basalts the degree of titanomagnetite lowtemperature oxidation, and hence the Curie temperature, increases with the age of the rock. The rate of increase will depend on various physical parameters of the rock as well as primary titanomagnetite composition and grain size. However, given a sufficiently large portion of the crust, these various parameters may vary systematically and a uniform age-dependency can be assumed. form:

Ozima et al. (1974) assumed a process of the following

$$
\mathrm{z}=1-\mathrm{e}^{-\mathrm{t} / \tau}
$$

where $\mathrm{z}$ denotes the oxidation parameter, $\mathrm{t}$ the age of the rock and $\tau$ the time constant of the process. From their data they derived a time constant of $\tau=5 \times 10^{7} \mathrm{yr}$.

Using a much larger number of data from various DSDP drill holes, Petersen and Roggenthen (1980) observed a different age-dependency: two linear regions with a distinct change of slope at about $4.0 \mathrm{~m} . \mathrm{y}$. Between 0 and $4.0 \mathrm{~m}$.y., the slope $\mathrm{z} / \mathrm{time}=0.2 / \mathrm{m} . \mathrm{y}$.; between 4.0 and $20 \mathrm{~m} . \mathrm{y} ., \mathrm{z} / \mathrm{time}=$ $0.0014 / \mathrm{m}$.y. (Fig. 6A). The latter value is much less well defined.

If the relationship of Figure $6 \mathrm{~A}$ is valid for the oceanic basement in general, an age estimate of drill hole $648 \mathrm{~B}$ can be attempted using the mean of the titanomagnetite $z$-values of Table 1. This is shown in Figure 6B where the first 4 m.y. of Figure $6 \mathrm{~A}$ is redrawn in a different scale. An age of $0.7 \mathrm{~m} . \mathrm{y}$. is obtained for Hole 648B.

It is not clear so far if the samples with $\mathrm{z}=0$ represent a younger lithologic unit or if variations of the local environment are the cause for a corresponding range of $z$-values in rocks of one and the some age.

The age estimate of Hole 648B above implies the following two assumptions:

1. The $50 \mathrm{~m}$ of basalt drilled in Hole $648 \mathrm{~B}$ is representative of the upper 100-200 m of crust (the data of Fig. 6A and -B represent mean values over a depth range of 100-200 m).

2. The initial titanomagnetite oxidation state in oceanic basalts immediately after emplacement is $\mathrm{z}=0$. If this assumption is not correct, i.e., a $z>0$ is present in zero-age rock (due to primary oxidation in the course of the initial cooling of the crust), a correspondingly younger age has to be assumed for Hole 648B.

If the age estimate of Hole $648 \mathrm{~B}$ is correct, then there is a considerable age discrepancy between Hole $648 \mathrm{~B}$ and the FAMOUS area (the latter being approximately $0.1 \mathrm{~m} . \mathrm{y}$. old; Prévot et al., 1979), even though both sites have nearly 


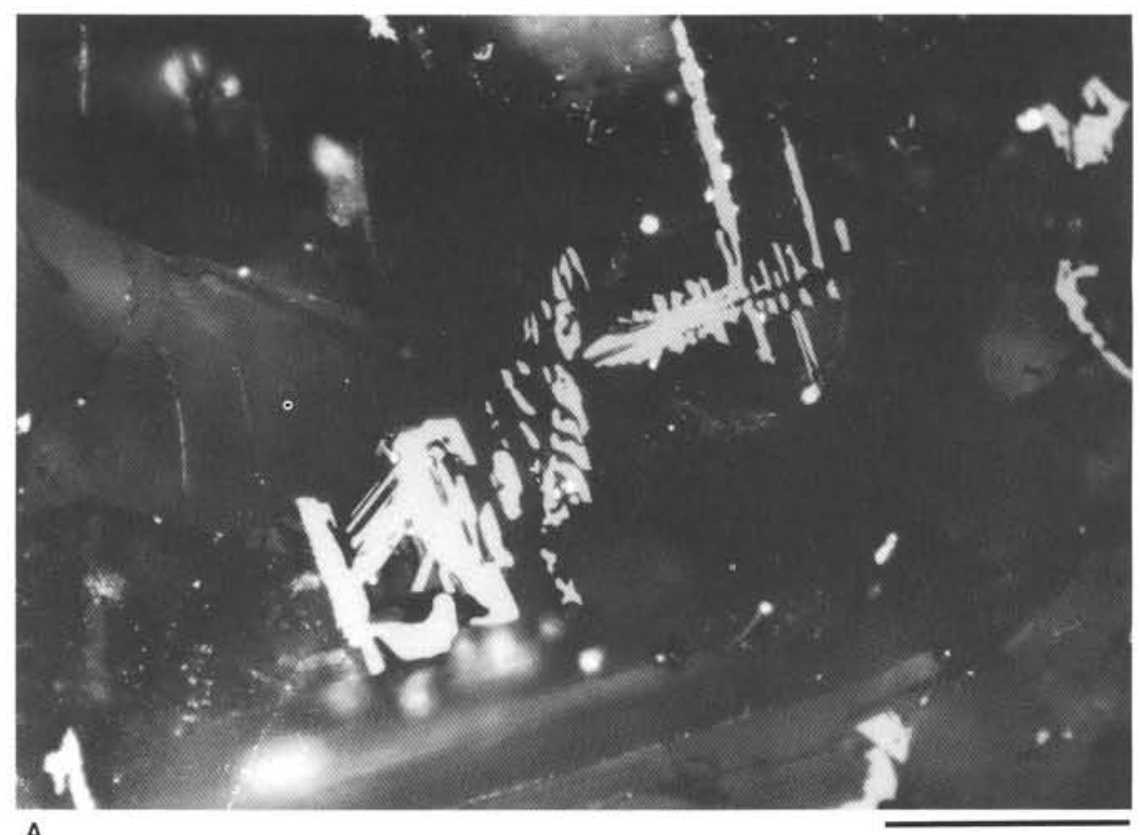

A

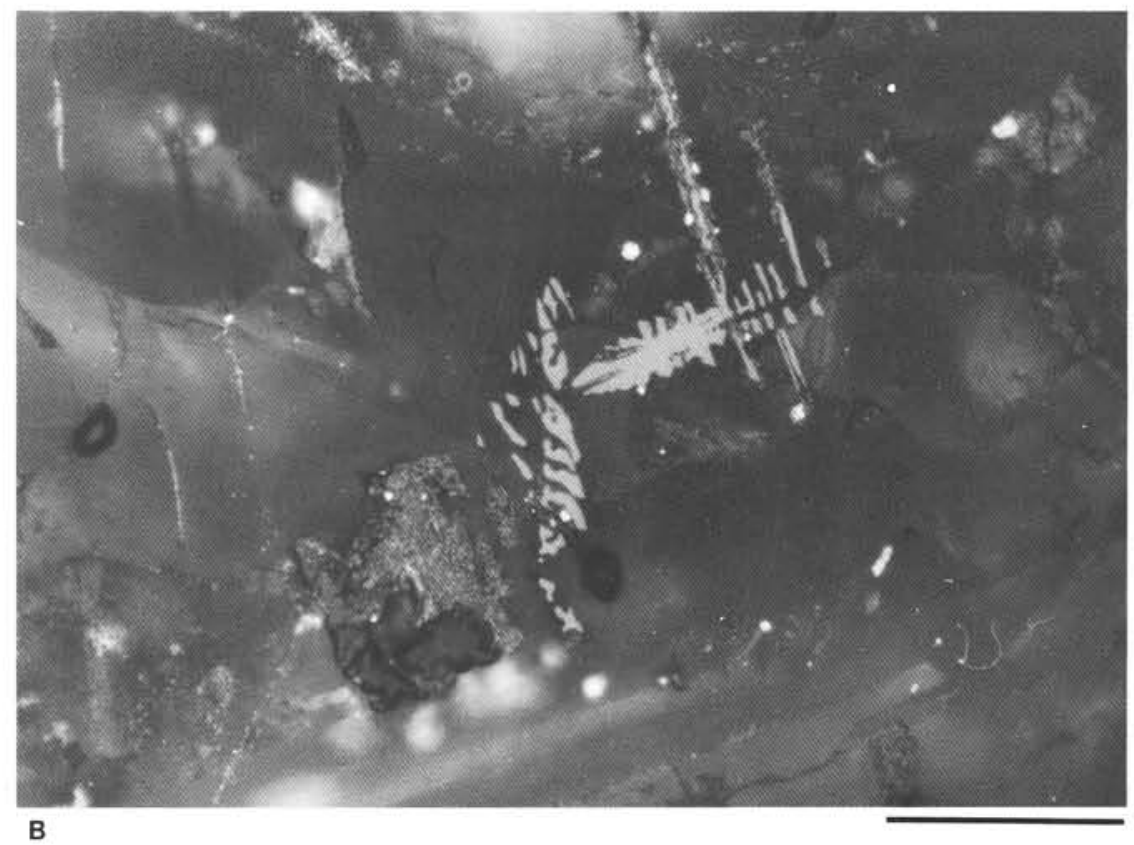

Figure 2. A. Skeletal titanomagnetite (light grey), lath-shaped ilmenite (grey) and globules of iron-sulfide (white). Sample 648B-6R-1, 53-54 cm. Oil immersion. The bar represents 50 $\mu \mathrm{m}$. B. Same as in A, but treated with magnetic colloid. The ferrimagnetic titanomagnetite grains are covered with colloid, whereas ilmenite and the globules of iron-sulfide remain uncovered.

identical z-values. An explanation for this apparent contradiction could be the fact that the FAMOUS samples investigated so far are dredge samples and all extremely fine grained material. The age-curve of Figure 6 , on the other hand, is obtained from drill cores with material which is on average coarser grained. As the titanomagnetite oxidation rate is also a function of grain size, the relatively high $z$-value of the FAMOUS samples could be explained this way.

\section{ACKNOWLEDGMENTS}

We are grateful to the two reviewers of this article for their critical and helpful comments. This work has been supported by the Deutsche Forschungsgemeinschaft.

\section{REFERENCES}

Bleil, U., and Petersen, N., 1983. Variations in magnetization intensity and low-temperature titanomagnetite oxidation of ocean floor basalts, Nature, 301:384-388. 
Grommé, C. S., Wright, T. L., and Peck, D. L., 1969. Magnetic properties and oxidation of iron-titanium oxides in Alae and Makaopuhi lava lakes, Hawaii, J. Geophys. Res., 74:5277-5293.

Housden, J., 1986. A magneto-mineralogical study of igneous rocks from the Rhum layered intrusion and the oceanic basement (Ph.D. dissert.). School of Physics, Univ. of Newcastle upon Tyne.

Irving, E., 1970. The mid-Atlantic ridge at $45^{\circ} \mathrm{N}$. XIV. Oxidation and magnetic properties of basalt; review and discussion, Can J. Earth Sci., 7:1528-1538.

Johnson, H. P., and Hall, J. M., 1978. A detailed rock magnetic and opaque mineralogy study of the basalts from the Nazca Plate, Geophys. J. R. Astron. Soc., 52:45-64.

Johnson, H. P., and Melson, W. G., 1978. Electron-microprobe analyses of some titanomagnetite grains from Hole 395A. In Melson, W. G., Rabinowitz, P. D., et al., 1978. Init. Repts. DSDP, 45: Washington (U.S. Govt. Printing Office), 575-579.

Katsura, T., and Kushiro, I., 1961. Titanomaghemite in igneous rocks, Am. Mineral., 46:134-145.

Larson, E. E., and Strangway, D. W., 1969. Magnetization of the Spanish Peak dike swarm, Colorado and Shipwreck Dike, New Mexico, J. Geophys. Res., 74:1505-1514.

Marshall, M., and Cox, A., 1972. Magnetic changes in pillow basalts due to sea floor weathering, J. Geophys. Res., 77:6459-6469.

O'Reilly, W., and Banerjee, S. K., 1967. The mechanism of oxidation in titanomagnetites: a magnetic study, Min. Mag., 36:29-37.

Ozima, M., Joshima, M., and Kinoshita, H., 1974. Magnetic properties of submarine basalts and the implications on the structure of the oceanic crust, J. Geomag. Geoelectr., 26:335-354.

Petersen, N., Bleil, U., and Eisenach, P., 1979. Low temperature alteration of the magnetic minerals in ocean floor basalts. In
Talwani, M., Harrison, C. H. and Hayes, D. E. (Eds.), Deep Drilling Results in the Atlantic Ocean: ocean crust. Am. Geophys. Union Maurice Ewing Series 2: Washington, 169-209.

Petersen, N., and Roggenthen, W. M., 1980. Rock and paleomagnetism of Deep Sea Drilling Project Leg 54 basalts - East Pacific Rise and Galapagos Rift. In Rosendahl, B. R., Hekinian, R., et al., Init. Repts. DSDP, 54: Washington (U.S. Govt. Printing Office), 865-877.

Petersen, N., and Vali, H., 1987. Observation of shrinkage cracks in ocean floor titanomagnetites, Phys. Earth Planet. Int., 46:197-205.

Prévot, M., 1973. Oxydation basse température des titanomagnétites et variation de l'intensité d'aimantation des basaltes oceaniques au voisinage de l'axe de la dorsale médio-atlantique, C. R. Acad.Sci., 277D:1101-1104.

Prévot, M., Remond, G., and Caye, R., 1968. Etude de la transformation d'une titanomagnétite en titanomaghémite dans une roche volcanique, Bull. Soc. Fr. Mineral. Cristallogr., 91:65-74.

Prévot, M., and Grommé, S., 1975. Intensity of magnetization of subaerial and submarine basalts and its possible change with time. Geophys. J. R. Astr. Soc, 40:207-224.

Prévot, M., Lecaille, A., and Hekinian, R., 1979. Magnetism of the mid-Atlantic ridge crest near $37^{\circ} \mathrm{N}$ from FAMOUS and DSDP results: a review, In Talwani, M., Harrison, C. H., and Hayes, D. E. (Eds), Deep Drilling Results in the Atlantic Ocean: ocean crust. Am. Geophys. Union, Maurice Ewing Series 2: Washington, 210-229.

Date of initial receipt: 29 June 1988

Date of acceptance: 8 December 1988 Ms 106/109B-156 


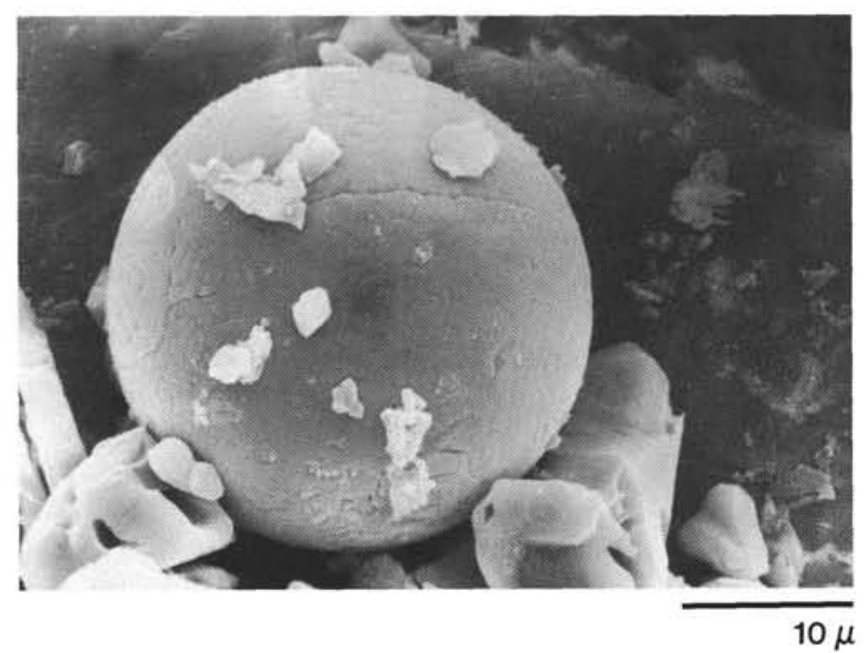

Figure 3. SEM image of large, perfectly spherical sulfide globule, isolated from groundmass, after 5 min etching with $10 \%$ HF. The globule consists of a complex intergrowth of probably pyrrhotite and pyrite. Relics of skeletal titanomagnetite grains also visible. Sample 648B-3R-1, 51-53 cm.

Table 2. Comparison of mean values of different rock magnetic parameters of Hole 648B and FAMOUS basalts.

\begin{tabular}{lcc}
\hline & Hole 648B & \multicolumn{1}{c}{ FAMOUS } \\
\hline $\begin{array}{l}\text { Specific saturation } \\
\text { magnetization } \\
\left(\text { Gauss } \mathrm{cm}^{3} / \mathrm{g}\right)\end{array}$ & $0.55 \pm 0.14(\mathrm{~N}=19)$ & $0.87 \pm 0.11(\mathrm{~N}=53)$ \\
$\mathrm{NRM}\left(10^{-3} \mathrm{Gauss}\right)$ & $9.37 \pm 4.32(\mathrm{~N}=17)$ & $14.4 \pm 12.3(\mathrm{~N}=103)$ \\
$\mathrm{MDF}(\mathrm{Oe})$ & $78 \pm 50(\mathrm{~N}=17)$ & $359 \pm 51(\mathrm{~N}=53)$ \\
Curie temperature $\left({ }^{\circ} \mathrm{C}\right)$ & $150 \pm 27(\mathrm{~N}=19)$ & $159 \pm 9(\mathrm{~N}=86)$ \\
Oxidation parameter $\mathrm{z}$ & $0.15 \pm 0.14(\mathrm{~N}=19)$ & 0.2 \\
\hline
\end{tabular}

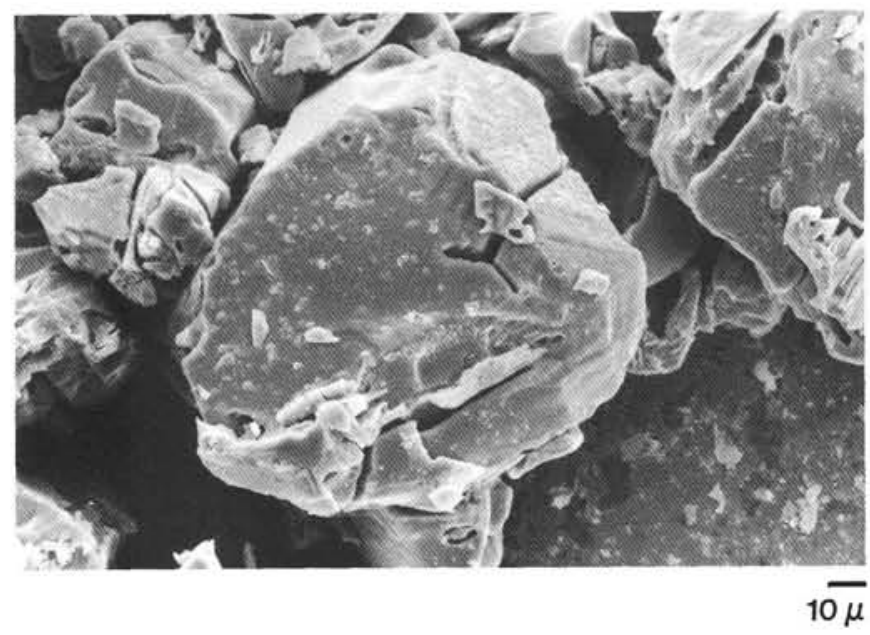

Figure 4. SEM image of titanomagnetite grain isolated from groundmass after 5 min etching with $10 \% \mathrm{HF}$. Shrinkage cracks visible in the upper and lower part of the grain. Titanomagnetite oxidation parameter $\mathrm{z}=0.38$. Sample $648 \mathrm{~B}-18 \mathrm{R}-1,25-27 \mathrm{~cm}$.

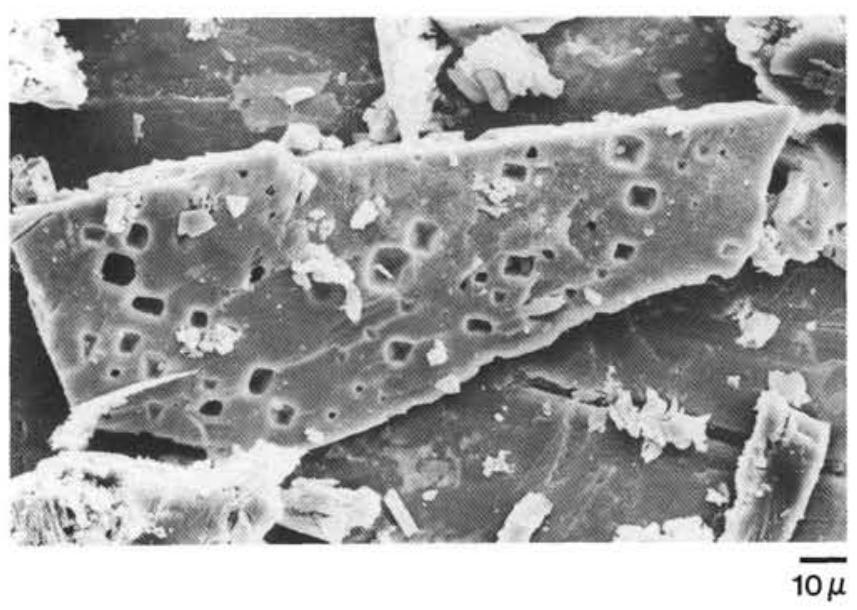

Figure 5. SEM image of titanomagnetite grain isolated from groundmass after 5 min etching with $10 \%$ HF. No shrinkage cracks visible. Abundant etch pits indicate high density of lattice defects. Titanomagnetite oxidation parameter $\mathrm{z}=0$. Sample $648 \mathrm{~B}-3 \mathrm{R}-1,51-53 \mathrm{~cm}$. 

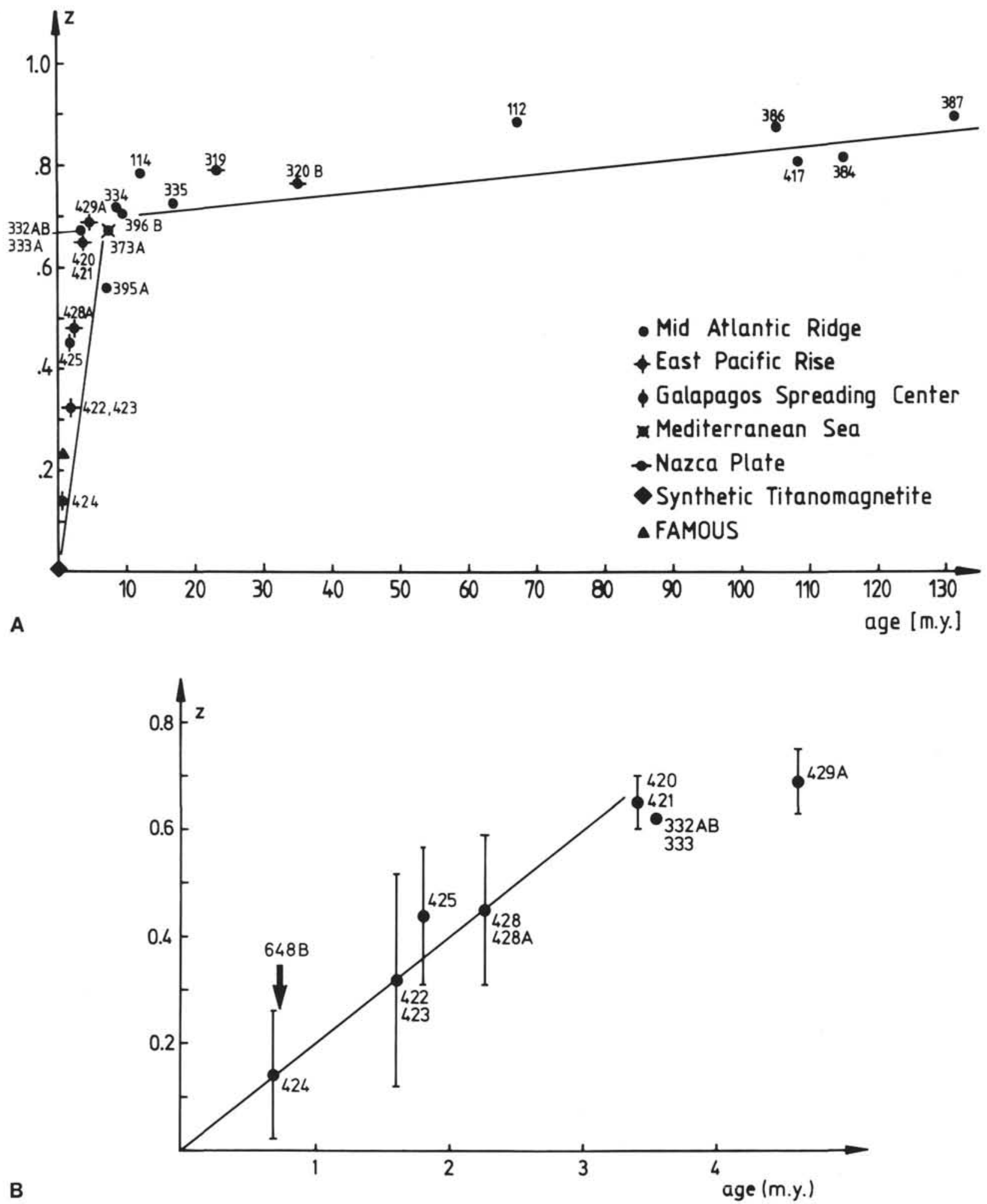

Figure 6. A. Mean values of titanomagnetite oxidation parameter, $z$, plotted against the ages of basalts from different DSDP holes. B. The first $4 \mathrm{~m} . \mathrm{y}$. of $\mathrm{A}$ are redrawn in a different scale. Hole $648 \mathrm{~B}$ mean oxidation parameter $\mathrm{z}=0.15$ corresponds to an age of 0.7 m.y. 